\title{
Structural changes in the meat market
}

\author{
Yu.O. Lupenko ${ }^{1}$, N.Hr. Kopytets ${ }^{1, *}$, and V.M. Voloshyn ${ }^{2}$ \\ ${ }^{1}$ National Scientific Center "Institute of Agrarian Economics", 03127, 10, Heroiv Oborony st., Kyiv, \\ Ukraine \\ ${ }^{2}$ National Science Center "Institute of Agriculture of the National Academy of Agrarian Sciences of \\ Ukraine", 08162, 2-B, Mechanical Engineers st., Chabany, Ukraine
}

\begin{abstract}
In the article it was determined that significant changes have taken place in the meat market of Ukraine as a result of the reformation processes in the country and in the agricultural sector. The dynamics of meat production in general and by main types were analyzed. The comprehensive analysis of the balances of beef, pork and poultry meat has been carried out. Meat producers are increasing their production volumes with a decline in certain branches of animal husbandry, and, accordingly, the structure of production is changing. The share of pork meat and beef meat decreased significantly, while the share of poultry meat production increased. The structure of the meat market was considered and the features of its functioning were revealed. It has been determined that the poultry meat market is competitive and efficient among other meat markets. The poultry industry has consistently maintained positive production dynamics over the past years. The pork market is fluctuating due to outbreaks of African swine fever and competition from the poultry market. The beef market is at a loss. It was argued that an increase in the poultry population, production volumes and the share of poultry meat in the structure of the meat market is a modern global trend. This was justified by affordability, cultural aspects, increased attention to the environment and personal health. Further development of the meat market depends on the prioritization of development and mechanisms of state support.
\end{abstract}

\section{Introduction}

The core of any economic system is agriculture, as a source of food supply for the population of the country. Taking this into account, the effective development of the agricultural sector was achieved by ensuring an acceptable level of food consumption, which reflects the standard of living of the country's population, therefore food security is an integral feature of its economic growth [1].

Dynamic and structural changes in agriculture indicate the need to clarify the prospects for the development of the industry, determine the main directions and quantitative parameters of its development, the nature and content of mutual influence [2].

Structural changes in the components of the agroeconomic system in a certain way influenced the indicators of the development of its potential. This happened because of

\footnotetext{
* Corresponding author: nataliia_kopitets@ukr.net
} 
reforms in the process of transition from a planned distribution to a market model of management. Among the most transformed, we note the resource potential, since the components of the organizational and economic mechanism, legal norms were changed.

The meat market is an integral part of the domestic agri-food market. There is forming a capacious and specific environment for the development of market relations, in which virtually every resident of the country participates, regardless of his nationality, food traditions, socio-economic status in society and income level [3].

Undoubtedly, the issue of assessing the state and structural changes of the domestic meat market is relevant and timely. The production and processing of meat play an important role in the implementation of the state economic policy in the field of ensuring the country's food security, aimed at a reliable supply of the country's population with high-quality food. The need to develop the agro-industrial complex of Ukraine is also due to the aggravation of competition between domestic and imported goods. Identification of the main problems facing meat producers contributes to the adoption of informed management decisions to support them [4].

Literature review: Structural transformations in agriculture in Poland and Ukraine were the subject of research by Heldak M., Kucher A., Stacherzak A., Kucher L. [5]. The factors influencing the production of red meat in Turkey were analyzed using the analytical approach of Simsek E. [6]. The comprehensive comparative analysis of the main types of meat products on the foreign market was carried out in the course of the research Ibatulina M.I., Varchenko O.M., Svinous I.V., Gury A.M., Mykytyuka D.N. [7]. Putsenteylo P.R [8] considered the issues of competitiveness of beef cattle breeding and the specifics of the development of the meat products subcomplex of Ukraine, as one of the main producers of important protein products that have biological value for the human body. Charykova O.G. and Popova E.A. assessed the state and development prospects of the regional beef market [9]. Hessle A. et al. [10] studied the combination of environmentally and economically sustainable production of dairy products and beef in Sweden. Analysis of production and consumption of meat in the world was carried out by A. Nasyrova [11]. Impacts of Covid-19 and price transmission in U.S. meat markets were researched Ramsey A.F. et al. [12].

\section{Materials and methods}

The purpose of the study is to identify structural changes in the meat market, highlight and generalize the main problems of its functioning.

The methodological research toolkit includes a systematic approach to cognition of economic phenomena and processes, as well as their interrelationships. During the research, general scientific and special methods of scientific knowledge were used. Thus, abstract and logical, monographic methods were used in the process of generalizing scientific literature and forming the conclusions of the study. The method of systems analysis made it possible to determine the main problems of the functioning of the meat market and to research its structure. Statistical and economic methods were used in processing statistical information, in particular, determining the dynamics of production volumes in the context of certain types of meat and major producers.

The information base was the data and analytical reports of the State Statistics Service of Ukraine and the Food and Agriculture Organization of the United Nations (FAO).

\section{Results and Discussion}

The meat market is an important component of the food market, the stability of the functioning of which largely depends on the standard of living of the population and ensuring 
the food security of the country. Meat and meat products are among the most important food products [13].

The main sources of meat are certain types of domestic animals, in particular cattle, pigs and poultry, and to a lesser extent buffaloes, sheep and goats. The use and further consumption of various animal species varies depending on the cultural preferences and religious beliefs observed.

The pig market, the livestock market and the poultry market are the main components of the meat market.

The balance of the meat market best reflects its state. The total supply of beef and veal in 2019 increased by $2.2 \%$ compared to 2018 and amounted to 416 thousand tons. Stocks of beef and veal decreased by $6.0 \%$. Imports remained at the level of 2018 , while exports increased by $3.6 \%$. Personal consumption of beef and veal by the population increased by $1.9 \%$ to $7.7 \mathrm{~kg}$. Stocks at the end of the year increased by $3.1 \%$.

In 2019 , the total pork supply decreased by $2.4 \%$ compared to 2018 to 856 thousand tons. Pork stocks at the beginning of 2019 increased by $3.2 \%$. Imports increased by $2.3 \%$ against the level of 2018 , while exports increased by $22.2 \%$. Personal consumption of pork by the population decreased by $2.7 \%$ and amounted to $19.0 \mathrm{~kg}$. Pork stocks at the end of the year increased by $7.0 \%$.

In 2019 , the total supply of poultry meat increased by $8.6 \%$ compared to the previous year and amounted to 1,615 thousand tons. Stocks at the beginning of the year decreased by $6.0 \%$. Imports remained at the level of 2018 and accounted for $3.8 \%$ of the total supply. Exports increased by $26.4 \%$. Personal consumption by the population increased by $3.5 \%$ to $26.0 \mathrm{~kg}$. Stocks of poultry meat at the end of the year increased by $2 \%$.

The item of the balance sheet "production" deserves special attention. In Ukraine, 2,492 thousand tons of meat were produced in 2019 . This were by $49.9 \%$ more than in 2000 and $5.8 \%$ more than in 2018 (Table 1).

Table 1. Structural changes in meat production by species in carcass weight, thousand tons.

\begin{tabular}{|c|c|c|c|c|c|c|c|c|c|}
\hline \multirow[b]{2}{*}{ Indicator } & \multicolumn{2}{|c|}{2000} & \multicolumn{2}{|c|}{2010} & \multicolumn{2}{|c|}{2018} & \multicolumn{2}{|c|}{2019} & \multirow[b]{2}{*}{$\begin{array}{l}2019 \text { to } \\
2000, \%\end{array}$} \\
\hline & 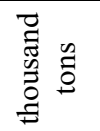 & $\partial^{\circ}$ & 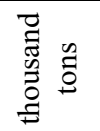 & $\partial^{0}$ & 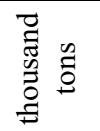 & $\partial^{\circ}$ & 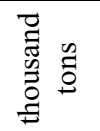 & $a^{\circ}$ & \\
\hline Meat - total & 1662.8 & 100.0 & 2059.0 & 100.0 & 2354.9 & 100.0 & 2492.4 & 100.0 & 149.9 \\
\hline Including: & & & & & & & & & \\
\hline Beef and veal & 754.3 & 45.4 & 427.7 & 20.8 & 358.9 & 15.2 & 369.5 & 14.8 & 49.0 \\
\hline Pork & 675.9 & 40.6 & 631.2 & 30.7 & 702.6 & 29.8 & 708.3 & 28.4 & 104.8 \\
\hline Poultry & 193.2 & 11.6 & 953.5 & 46.3 & 1258.9 & 53.5 & 1381.4 & 55.4 & 715.0 \\
\hline
\end{tabular}

Source: Developed by the author according to the State Statistics Service of Ukraine [14].

Beef and veal production in 2019 were decreased by $51.0 \%$ compared to 2000 and increased by $3.0 \%$ compared in 2018 . to 369.5 thousand tons. In the analyzed period, pork production increased by $4.8 \%$ compared to 2000 and by $0.8 \%$ compared to 2018 amounted to 708.3 thousand tons. Poultry meat production in 2019 increased by 7.2 times compared to 2000 and increased by $9.7 \%$ against the level of 2018, amounted to 1,381.4 thousand tons.

In 2019 , mMore than $50 \%$ of production volumes in the meat market of all types were formed at the expense of four regions. In particular, the Vinnytsia region was produced $18.4 \%$ of the volume of meat supply, Cherkassy $-14.0 \%$, Dnepropetrovsk $-10.2 \%$ and Kiev region $-8.7 \%$. The largest share of these regions in meat production were explained by the fact that on their territory the largest poultry factories and livestock complexes were located.

Transformational processes have taken place in the animal husbandry of Ukraine, which led to changes in the structure of the meat market. Thus, the share of poultry meat in the 
structure of production of all types of meat increased from $11.6 \%$ to $55.4 \%$ from 2000 to 2019. It should be noted that agricultural enterprises have increased their production of poultry meat. They hold more than $50 \%$ of the total poultry population and provide more than $85 \%$ of poultry meat production. The main producer and exporter of poultry meat was MHP. The increase in production capabilities in agricultural enterprises were primarily promoted by the price, since poultry meat was cheaper in comparison with other types of meat. And quality of the poultry meat, which was confirmed by its competitiveness both in the domestic and foreign markets. Domestic supply of poultry meat fully meets domestic demand.

It should be stated that since 2014, the domestic pork market has been destabilizing. In particular, a decrease in the number of pigs and meat production, a decrease in demand and a decrease in exports. In the structure of meat production in Ukraine, the share of pork has a clear tendency to decline. In 2019, it was $28.4 \%$, while in 2000 it was $40.6 \%$.

The proportion of beef and veal in the structure of production of all types of meat decreased to the critical level. In 2000, the beef and veal amounted to $45.4 \%$, then in $2019-$ only $14.8 \%$. This actually narrows the formation of a rational meat balance of the country where beef must take at least $30 \%$. Such structural changes have become the result of crisis phenomena in the field of cattle breeding [15].

It was determined that the structure of the main meat producers has changed significantly. The production of all types of meat was concentrated by $2 / 3$ in agricultural enterprises. In 2019 , the share of these farms in the total production volume amounted to $68.1 \%$. In addition, is growing from year to year. It should be noted that in 2000 , households were the main meat producers. They produced $73.6 \%$ of all types of meat. The dominance of the production of the main types of livestock products in the households was due to several circumstances. First, there were different vector directions of development of animal husbandry in the private sector during 1990-2009. This has led to the cessation of production of the corresponding products in most farms of the corporate sector. Secondly, the production of livestock products for most rural households were a source of cash and food $[13,16]$.

Pork production seemed to have stabilized. However, African swine fever was caused significant damage. Raising cattle remains an unprofitable business. In Ukraine, the trend of cutting out cattle continues in the future. At the same time, households of the population remain the main producers of cattle meat. The rapid return on investment in the production of poultry meat led to an increase in investment in this industry, the construction of modern large poultry farms and the creation of powerful vertically integrated companies [4].

Domestic production of poultry products is one of the most economically attractive and competitive types of agribusiness. This evidenced by the annual steady dynamics of growth in poultry meat production. However, due to high competition in consumer markets, production must constantly improve technologies for growing poultry, processing poultry products, introduce modern quality standards, a planning strategy etc. In addition, poultry farming has a high export potential and prospects for its growth [17].

The poultry and pig breeding are developing in Ukraine. The production of beef is becoming less profitable every year. In 2018, Ukraine had only $13.5 \%$ of the cattle population that was in the country in 1991. First, the problem was in the price. According to market players, no matter how prices change, beef always costs 30-35\% more expensive than pork. This significantly was reduces the demand for it. In addition, if the project for the construction of a pig farm pays off in five to six years, then investments in cattle - within ten to fifteen years. Only a few agricultural holdings are engaged in the production of beef. And this as a side project of the dairy business [16].

The meat market offers a wide range of various meat products, but the low level of purchasing power remains the most significant obstacle to meeting the needs of the population for these food products. 


\section{Conclusions}

The comprehensive analysis of the balances of beef, pork and poultry meat has been carried out. Attention was focused on assessing the dynamics of production volumes of the main types of meat. The results of the research indicate that radical structural changes have been in the meat market in 2000-2019. In particular, in the structure of meat production, the share of pork and beef was decreased significantly, while the share of poultry meat production was increased. At the same time, the production of all types of meat were concentrated mainly in agricultural enterprises.

The agricultural enterprises hold more than $50 \%$ of the total poultry population and provide more than $85 \%$ of poultry meat production was revealed.

It was substantiated that the increase in the poultry population, production volumes and the share of poultry meat in the structure was not an internal feature of the Ukrainian meat market. This is a modern global trend. It based on both the affordability of poultry meat, environmental or health reasons, and cultural considerations. In particular, poultry meat allowed to be consumed by all widespread world confessions. While Hindus do not consume beef, and Muslims do not consume pork.

For the development of the meat market, measures are needed to improve the situation in all segments of the meat market (livestock production, processing of raw meat and sale of final products). All this requires a clear definition of the priorities for the development of the meat market and the mechanisms of state support for the livestock industry. Further development of the meat market in Ukraine will largely depend on the development trends of the world meat market.

\section{References}

1. L. Hlubish, Agrarian Economics 6, 1-2, 24-27 (2013)

2. Yu.O. Lupenko, Ekonomika APK, 11, 10-14 (2012)

3. V.M. Tsikhanovska, Development of the agro-food market of Ukraine in the conditions of globalization, (Vinnytsia: Vinn. city printing, 2014)

4. N.Hr. Kopytets, V. M. Voloshyn, In: V. Korneev et al. Corporate law transformations of economic systems in the times of neo-industrialization, 290-300 (Nuremberg, Germany, 2020)

5. M. Heldak, A. Kucher, A. Stacherzak, L. Kucher, Journal of Environmental Management and Tourism, IX, 8(32), 1827-1841 (2018) https://doi.org/10.14505//jemt.v9.8(32).24

6. E. Simsek, Bulg. J. Agric. Sci., 26 (2), 282-292 (2020)

7. M. Ibatulin, O. Varchenko, I. Svynous, O. Klymchuk, O. Drahan, I. Herasymenko, Agricultural Science and Practice, 6(2), 29-46 (2019) https://doi.org/10.15407/agrisp6.02.029

8. P.R. Putsenteylo, Competitiveness of meat cattle in Ukraine: theory and practice, (Ternopil: VPC "Ekonomichna dumka TNEU”, 2011)

9. O.G. Charykova, E.A. Popova, The Modern Economy: problems and solutions, 1, 85-93 (2018) https://doi.org/10.17308/meps.2018.1/1786

10. A. Hessle, J. Bertilsson, B. Stenberg, K.-I. Kumm, U. Sonesson, Agricultural Systems, 156, 105-114 (2017) https://doi.org/10.1016/j.agsy.2017.06.004 
11. A.M. Nasyrova, Bulletin of the Moscow University named after S.Yu. Witte, Economics and Management, 1 (28), 61-65 (2019) http://dx.doi.org/10.21777/2587-554X-2019-161-65

12. A.F. Ramsey, B.K. Goodwin, W.F. Hahn, M.T. Holt, Agricultural Economics, 52, 441458 (2021) https://doi.org/10.1111/agec.12628

13. N.Hr. Kopytets, V.M. Voloshyn, Ekonomika APK, 6, 59-68 (2020) https://doi.org/10.32317/2221-1055.202006059

14. State Statistics Service of Ukraine. Retrieved from: http://ukrstat.gov.ua

15. N. Kopytets, V. Voloshyn, E3S Web of Conferences, 282, 07015 (2021) https://doi.org/10.1051/e3sconf/202128207015

16. I.B. Svynous, A.M. Gura, D.M. Mykytyuk, Economics and management of agriculture, 11, 29-33 (2013)

17. O.I. Furdychko, L.I. Svaliarchuk, O.L. Shevtsova, Balanced nature management 2, 5-11 (2019) https://doi.org/10.33730/2310-4678.2.2019.184040 